\title{
PENDIDIKAN ISLAM ABAD 21 PERSPEKTIF DISIPLINER DAN INTERDISIPLINER
}

\author{
Sitti Chadidjah ${ }^{1}$, Mohamad Erihadian $^{2}$, Asep Saefulmillah ${ }^{3}$ \\ ${ }^{1}$ Fakultas IImu Keislaman Universitas Muhmmadiyah Bandung, \\ ${ }^{2}$ Fakultas Tarbiyah IAILM SuryalayaTasikmalaya, \\ ${ }^{3}$ Universitas Islam Negeri Sunan Gunung Djati Bandung \\ sittichadidjah@staim-bandung.ac.id, \\ erihadiania@uinsgd.ac.id. \\ asepsapulmillah40@gmail.com
}

\begin{abstract}
This research is a study of disciplinary and interdisciplinary research in Islamic education dealing with 21 st century learning skills. The problem faced by Islamic education is the adjustment of Islamic education in the era of digitalization and learning in the 21st century with the aim of preparing generations of Muslims who are ready to live in accordance with their times. This study focuses on educational institutions and curriculum. The disciplinary approach is problem solving through a theological and interdisciplinary approach in question: problem solving through allied science including; educational philosophy, psychology, Islamic education. This study uses a qualitative approach with literature study as a basis for data collection. One of the characteristics of qualitative research is to explore issues thoroughly, from various books and journals related to the theme, both from within and outside the country, then analyzed.This paper produces 1) one discourse that the disciplinary and interdisciplinary approach is able to solve the problems faced by Islamic education in the 21st century, 2) the disciplinary and interdisciplinary blend of concepts that are inseparable in solving and dealing with current Islamic education problems.
\end{abstract}

Key words: Disipliner, Interdisipliner, Islamic Education

\begin{abstract}
Abstrak
Penelitian ini merupakan kajian riset disipliner dan interdisipliner dalam pendidikan Islam mengahadapi skill pembelajaran abad 21. Permasalahan yang dihadapi pendidikan Islam adalah penyesuaian pendidikan Islam era digitalisasi dan pembelajaran abad 21 dengan tujuan mempersiapkan generasi Islam yang siap hidup sesuai dengan zamannya. Kajian ini fokus pada lembaga pendidikan dan kuruikulum. Pendekatan disipliner merupakan pemecahan masalah melalui pendekatan teologis dan interdisipliner yang dimaksud adalah pemecahan masalah melalui ilmu yang serumpun diantaranya; filsafat pendidikan, psikologi, ilmu pendidikan Islam. Penelitian ini menggunakan pendekatan kualitatif dengan studi pustaka sebagai dasar pengumpulan data. Satu diantara ciri penelitian kualitatif adalah mengeksplorasi permasalahan saksama, dari berbagai buku dan jurnal terkait tema, baik itu dari dalam dan luar negeri, lalu dianalisis. Tulisan ini menghasilkan 1) satu wacana bahwa pendekatan disipliner dan interdisipliner mampu menyelesaikan permasalahan yang dihadapi oleh pendidikan Islam di abad 21,2) disipliner dan interdisipliner perpaduan konsep yang tidak terpisahkan dalam menyelesaikan dan menghadapi permasalahan pendidikan Islam saat ini.
\end{abstract}

Kata Kunci: Disipliner, Interdisipliner, Pendidikan Islam

\section{PENDAHULUAN}

Tren dunia dilipat ditandai dengan adanya komputer dilipat, ruang kerja yang hanya sebesar ukuran buku. ${ }^{1}$ Tren ini pada awalnya belum menggemingkan banyak orang. Namun kemudian seiring perubahan-perubahan yang cepat baik dalam alat, budaya maupun perputaran bisni, telah membuka 


\section{Fastabiq: Jurnal Studi Islam \\ ISSN 2723-0228}

Volume 1 Nomor 1 Juni 2020

mata khalayak. Kasus Nokia yang telah bertahan selama kurang lebih belasan tahun di dunia membuat perusahaan ini terlena tanpa pesaing. Android yang membawa Samsung mengubah segalanya dengan menciptakan demand dan trend, melesat mengalahkan Nokia.

Kondisi di atas menunjukkan bagaimana teknologi mengubah segalanya dengan cepat. Perubahan itupun tentu melanda dunia pendidikan. Sejauh ini terkesan respon dunia pendidikan, masih pada sebagai lifestyle saja belum pada esensi. Pembelajaran abad 21 menuntut media bukan lagi sebagai media. Media juga dapat bertindak sebagai lingkungan dan bahkan sumber belajar. ${ }^{2}$ Inilah yang terlihat belum digarap dengan serius dalam proses pembelajaran di Indonesia.

Di lain pihak, penggunaan teknologi dalam hal ini smartphone sudah menjadi bagian dari keseharian. Pengguna smartphone, misalnya, bukan hanya kalangan dewasa, melainkan juga anakanak usia sekolah. Sekolah agak malu-malu mengungkapkan akan kesulitan dalam belajar mengajar akibat siswa banyak mengakses smartphone saat guru sedang berceramah di kelas. Guru Bimbingan Konseling dihadapkan dengan permasalahan belajar baru, yang ternyata dampak dari kemajuan digital. Dunia pendidikan saat itu menutup rapat akan dampak dari digital ini terhadap anak didiknya. Mengingat dampaknya yang demikian luas dari kemajuan dunia digital, Elly Risman bersama yayasan Buah Hati berbicara dari seminar ke seminar tentang dampak gawai bagi anak.

Tuntutan pembelajaran dewasa ini di tengah realita budaya teknologi yang tidak bisa dihindari. Semua lini pendidikan dituntut untuk menciptakan manusia yang mampu:1) berkomunikasi secara global lintas negara, budaya dan agama, 2) Collaboration Skill kemampuan berkerjasama dengan bangsa sendiri dan bangsa lain secara terbuka dan transparan, 3) Creativity, kreatif dalam mencari solusi, berinovasi dan mampu menghasilkan sesuatu yang baru, 4) Critical Thinking mampu berfikir kritis dalam menghadapi informasi domestik dan global. Keempat hal ini disebut $4 \mathrm{C}$ pembelajaran abad 21 atau kemampuan global yang harus dimiliki siswa hari ini dan nanti.

Merespon globalisasi yang diiringi kemajuan digital yang sangat cepat, apalagi fenomena pandemi yang merupakan bencana nasional ini menuntut semua komponen pendidikan beralih pada sistem pembelajaran daring. Pemberlakuan kurikulum 2013 oleh pemerintah merupakan titik awal pembelajaran abad 21 di Indonesia, dimana pelajar sebagai student center, guru sebagai motivator, guide, atau fasilitator. Kendala yang dihadapi kurikulum 2013 terdapat pada 1) guru sebagai sumber utama pembelajaran, penyebabnya adalah keterlambatan sosialisasi dan pelatihan K13 yang diberikan pemeritah kepada guru 2) sarana dan prasarana yang minim. ${ }^{3}$ Pada penelitian yang berbeda pada tahun 2018 mengatakan hal yang sama yaitu lemahnya pemberdayaan guru, karena pelatihan $\mathrm{K} 13$ terlambat. ${ }^{4}$

Globalisasi melahirkan tantangan tersendiri seperti kasus di Kanada, pemerintah mempersiapkan guru mata pelajaran kewarganegaraan untuk dilatih pada program Educating for Global Citizentship. Hal ini dilakukan karena arus migrasi dan urbanisasi terjadi masif. Penelitian ini dilaksanakan selama 3 tahun dan menemukan bahwa guru dihadapi pada peluang dan tantangan unik dalam belajar mendidik kewarganegaraan global. Selanjutnya penelitian ini menyarankan perlunya pengintegrasian pendidikan kewarganegaraan global ke dalam pendidikan guru melalui pendekatan holistik. Strategi mengajar yang digunakan adalah strategi Project base learning, Project 


\section{Fastabiq: Jurnal Studi Islam}

ISSN 2723-0228

Volume 1 Nomor 1 Juni 2020

oriented Learning dan coopertive learning ketika diintegrasikan dengan teknologi web 2, memotivasi rasa ingin tahu, berfikir kritis, dan komuniktif pelajar Temuan ini memberikan alternatif strategi pembelajaran abad 21.

Derasnya arus informasi di dunia maya dan kemudahan akses informasi, menjadikan informasi sangat murah. Kapanpun dan dimanapun seorang pelajar bisa mengakses. Kemudahan ini diasumsikan pelajar bisa mengetahui satu materi sebelum guru mata pelajaran tersebut mengajar. Sehingga ketika guru menggunakan strategi dan metode ceramah yang monoton, akan menimbulkan rasa bosan yang berkepanjangan yang mengakibatkan proses belajar mengajar kurang efektif. Oleh karena konsep guru penggerak yang diungkapkan Menteri Pendidikan menjadi relevan. Kondisi ini menghantarkan guru sebagai fasilitator, guide, motivator dan konsultan. ${ }^{5}$

Informasi yang tersebar di dunia maya, satu tahun ini menimbulkan masalah besar bangsa. Mudahnya hoax ini diterima seolah-olah mengandung mantra kebenaran. Orang yang berpendidikan pun terpengaruh. Bahkan analisa dan prinsip-prinsip fondamental keilmuan dan dasar agama yang puluhan tahun dianut terlupakan. Kejadian ini cerminan ketidak-siapan dalam menyikapi berita. Islam mengajarkan konsep tabayun. Kata tabayun mengandung arti teliti, hati-hati, sikap kehati-hatiannya dibarengi dengan recheck dan crosscheck. Quraish Shihab menafsirkan fathabayyanuu Al Hujurat Ayat 6 , teliti dengan sungguh-sungguh, ${ }^{6}$ dan tabayyun dalam arti bahasa adalah penjelasan dengan sejelas-jelasnya.Ketelitian mengandung makna teknis yaitu memilah, memilih, memikirkan kelogisan informasi, sehingga kita tidak terjebak. Sayangnya yang menjadi korban hoax umat muslim. Fenomena ini sebagai indikasi perlunya critical thinking dalam menghadapi informasi bebas. menunjukkan bahwa pendidikan Islam belum memberikan hasil

Sisi lain konsep teologi telah lama menawarkan perilaku tabayyun yang merupakan akhlak yang mulia dalam Islam, Perilaku tabayyun ini adalah cek dan recek ketika seseorang menerima sebuah informasi dimana ada proses penelusuran informasi kebeberapa sumber, dan ketika sampai pada sumber inti, diharuskan juga melihat akhlak dari sumber utama. Hal ini juga dicontohkan para perawi hadis, yang mengecek sumber datangnya hadits ketika akan membukukan hadits. Patricia C. Seifert, mendifinisikan less formal and skeptical difinition of critical thinking: deciding what to do and when, where, why and how to do it. ${ }^{7}$ Bisa dikatakan bahwa tabayyun yang termasuk pada kategori keterampilan critical thinking. Masih minimnya karakter tabayyun dikalangan umat saat ini yaitu mudahnya umat, terutama kaum mudah muslim terprovokasi informasi di medsos.

Fenomena di atas meninggalkan pekerjaan rumah yang sangat kompeks bagi pendidikan Islam diera pembelajaran abad 21. Pendidikan Islam harus merespon dengan cepat baik secara kelembagaan maupun substansi pendidikan. Secara kelembagaan, lembaga pendidikan Islam masih lemah secara organisasi namun tetap berusaha bertahan. Di samping itu, lembaga pendidikan cenderung mempertahankan konsep disipliner, yaitu menggunakan pendekatan teologis. Dari sisi content dalam hal ini kurikulum pendidikan Islam ditantang untuk mengintegrasikan materi pendidikan Islam kepada satu konsep yang mempersiapkan peserta didik agar mempunyai keterampilan abad 21. 


\section{Fastabiq: Jurnal Studi Islam}

ISSN 2723-0228

Volume 1 Nomor 1 Juni 2020

Konsep disipliner dalam kontek pendidikan Islam merupakan konsep teologi yang bersifat dogmatis dan sesuai tuntunan syariah yang sudah sangat lama diamalkan. Pendidikan Islam bertujuan membentuk manusia Insan Kamil, manusia yang sempurna lahir batin seperti yang diungkapkan Zakiah Darajat. ${ }^{8}$ Ihya Ulumudin juga menjelaskan bahwa hati selalu bertaqarrub kepada Sang Penciptanya oleh kerana itu manusia perlu latihan fisik dengan melakukan akhlak mahmudah, dan latihan spiritual dengan tazkiyatun nafs. ${ }^{9}$ Konsep pendidikan Islam merupakan turunan dari konsep yang paling tinggi melebih kemampuan nalar manusia yaitu konsep manusia sebagai khalifatullah dan konsep Abdullah pengemban amanah Allah di muka bumi ini. Lalu Allah memberikan manusia potensi yang disebut Fitrah. Potensi ini meliputi akal, hati dan kecenderungan baik dan tidak baik, yang akan dikembangkan lebih baik di dunia pendidikan Islam. Selanjutnya konsep prophetic yaitu diutusNya rasulullah saw, untuk menyempurnakan akhlak, maka manusia harus mempunyai prilaku yaitu akhlak yang baik. Pendidikan Islam bertugas membentuk akhlak yang baik.

Pendidikan Islam berlandaskan Al-Quran yang merupakan wahyu llahi dan hadits yang disampaikan melalui utusan Allah merupakan implementasi dari wahyu ilahi. Akal menempatkan posisi penting dalam perkembangan manusia oleh karena itu pembelajaran abad 21 yang didominasi oleh perkembangan nalar atau pemikiran, merupakan satu bagian dari perkembangan potensi manusia, sementara pendidikan Islam berorientasi kemajuan akal dan spiritual.

Pendekatan interdisipliner merupakan pendekatan yang menggunakan berbagai disiplin ilmu yang berasal dari rumpun yang sama. IImu pendidikan Islam yang terdiri dari ilmu pendidikan Islam, filsafat Pendidikan Islam, sejarah pendidikan Islam, ilmu pendidikan umum yaitu ilmu psikologi, ilmu pendidikan dan lainnya. Perpaduan ini (interdisipliner) untuk menyelesaikan permasalahan yang terjadi. Sementara disipliner merupakan pendekatan yang menggunakan satu disiplin ilmu. Kedua pendekatan ini akan digunakan sebagai pijakan dalam menyesuaikan pendidikan dan skill pembelajaran abad 21 dalam pendidikan Islam dan menjadi fokus pembahasan penulisan ini.

Skill pembelajaran abad 21 merupakan tantangan bagi dunia pendidikan Islam. Penelitian ini akan mengkaji lebih spesifik tentang 1) Apakah disipliner dan interdisipliner sepaham dengan fenomena global yaitu skill pembelajaran abad 21, 2) apakah pendekatan interdisipliner dan displiner satu kesatuan dalam mengatasi permasalahan pendidikan Islam. Penelitian ini bertujuan 1) mendapatkan titik temu antara disipliner dan interdisipliner terhadap fenomena global didunia pendidikan Islam yaitu skill pembelajaran abad 21. 2) menguatkan bahwa pendekatan disipliner dan interdisipliner merupakan satu kesatuan dalam pendidikan Islam, saling mendukung dan tidak bisa dipisahkan.3) skill pembelajaran abad 21 merupakan pergembangan dari fitrah manusia yang terdapat pada pendekatan disipliner.

\section{METODOLOGI PENELITIAN}

Penelitian ini menggunakan pendekatan kualitatif dengan studi pustaka sebagai dasar pengumpulan data. Satu diantara ciri penelitian kualitatif adalah mengeksplorasi permasalahan. Faktor yang harus dipertimbangkan dalam memilih pendekatan kualitatif diantaranya mempelajari tentang pandangan individu, mengakses proses dari waktu ke waktu, menghasilkan teori berdasarkan 


\section{Fastabiq: Jurnal Studi Islam \\ ISSN 2723-0228}

Volume 1 Nomor 1 Juni 2020

perspektif partisipan. ${ }^{10}$ Peneliti membaca secara saksama tentang jurnal dan buku pendidikan Islam dan pandangan disipliner dan interdisipliner, terutama tentang pembelajaran skill abad 21. Untuk mendapatkan informasi yang kuat, data riset-riset terkait, dikumpulkan kemudian dicari keterkaitan masing-masing komponen pembahasan, kemudian dianalisis dan disintesis kemudian didiskusikan dengan partner menjadi satu kesimpulan.

\section{PEMBAHASAN}

\section{Pendidikan Islam Dalam Perspektif Disipliner}

Disipliner adalah pendekatan satu disiplin ilmu yang digunakan untuk mengatasi permasalahan tertentu. Konsep disipliner dalam kontek pendidikan Islam merupakan konsep teologi yang bersifat dogmatis dan tuntunan syariah dan pada satu sisi bersifat fleksibel pada skala teknis. Sumber utama pendidikan Islam adalah Al-Quran dan hadits. Jelas dalam Surat Al-Mujadalah Ayat 11 bahwa Allah akan meninggikan derajat satu kaum yang mempunyai ilmu, Hai orang-orang beriman apabila dikatakan kepadamu: "Berlapang-lapanglah dalam majelis", maka lapangkanlah niscaya Allah akan memberi kelapangan untukmu. Dan apabila dikatakan: "Berdirilah kamu", maka berdirilah, niscaya Allah akan meninggikan orang-orang yang beriman di antaramu dan orang-orang yang diberi ilmu pengetahuan beberapa derajat. Dan Allah Maha Mengetahui apa yang kamu kerjakan. Masyarakat Islam berlomba-lomba menginginkan derajat yang tinggi melalui pendidikan karena bagi muslim pendidikan itu wajib.

Konsep khalifatullah menggiring manusi akan pentingnya Pendidikan. Allah menciptakan manusia, mengemban tugas sebagai perwakilan Allah untuk mengelola alam dan segala isinya. Oleh karena itu fitrah sebagai potensi utama manusia harus dikembangkan. Fitrah ini diartikan akal dan hati. Potensi akal itu diberikan dan dituntun Allah swt. Ali ra berpandangan bahwa akal itu terbagi dua, 1) yang dicetak sebagaimana Nabi saw berkata kepada Ali ra," Allah tidak menciptakan makhluk yang paling mulia daripada akal, dan 2) yang didengar, sebagaimaan Nabi saw berkata kepada Ali," apabila manusia mendekatkan diri kepada Allah swt dengan berbagai kebaikan, maka engkau telah mendekatkan pada akalmu. Hadits ini menjelaskan bahwa taqarrub (mendekatkan diri) itu harus diperoleh dengan usaha yang sungguh-sungguh. Gharizah Akal dalam proses menerima dan mengolah informasi harus sejalan dengan gharizah hati dan gharizah basyar. ${ }^{11}$ Akal dan hati pada perkembangannya harus dididik melalui proses pendidikan yang sistematis, sehingga terarah dan menghasilkan insan kamil seperti tujuan pendidikan islam yang diungkapkan Zakiah Darajat, pendidikan islam bertujuan membentuk manusia insan kamil, manusia yang sempurna lahir batin. ${ }^{12}$

Kajian telogis membuktikan bahwa manusia modern mendamba Allah, atau kerinduan pada kedamain batin dan kedamaian jiwa. Richard Gere mengakui akan kesempurnaan syariat dan tarekat/jalan spiritual dalam Islam, namun dia lebih memilih ritual Budha yang lebih bersifat temporer, berbeda dengan sholat, puasa bersifat kontinue terus menerus harus dilaksanakan. Barat dengan kemajuan intelektual, pada abad 20 mulai merasakan kebutuhan akan Tuhan. Melalui ritual spiritual yang mendalam, mereka mendapatkan kedamaian dalam hati, meski tidak banyak yang masuk Islam ketika itu, namun mereka sudah melirik ritual Islam. ${ }^{13}$ Berdirinya pesantren pertama di Amerika 


\section{Fastabiq: Jurnal Studi Islam \\ ISSN 2723-0228}

Volume 1 Nomor 1 Juni 2020

Serikat oleh Syams Ali dan di Australia oleh Muhammadiyah pada tahun 2019 adalah bukti bahwa Islam atau agama diterima di dunia yang mengagungkan akal.

Eksperimen sains membuktikan Tuhan ada pada setiap diri manusia, begitu juga para teolog katakanlah Schimmel, Ibn Arabi dan para sufi lainnya. Tuhan itu ada pada diri manusia, bahkan seorang sufi mengatakan bahwa nama Tuhan yang keseratus itu ada dan berada pada diri manusia. Berfikir bagaimana mendekati diri kepada Sang Khalik, melahirkan kreativitas yang bernama jalan, jalan menuju Tuhan. Ketika membahas jalan lebih dalam, muncul metode. Lahirlah yang bernama latihan, lalu berkembang secara massif menjadi satu kebutuhan manusia bernama pendidikan.

Pendidikan Islam secara teologis sangat menghargai potensi manusia. Potensi lahir karena manusia mengemban tugas sebagai manifestasi Tuhan di dunia, khalifah. Maka konsep khalifah dalam pendidikan Islam, terletak pada pandangan bahwa setiap manusia mempunyai nilai positif tentang kecerdasan, daya kreatif, dan keluhuran budi. ${ }^{14}$ Konsep fitrah yang menjadi ketentuan normatif dalam mengembangkan dan mengoptimalkan berbagai potensi kemanusiaan. ${ }^{15}$ Umat Islam harus mempertahankan kebutuhan mendasar manusia akan Tuhan melalui agama Islam yang sudah terbukti menjadi agama pilihan akhir zaman. Islam agama yang mempunyai kelengkapan beribadah secara lahir dan batin dan sudah terbukti membimbing manusia kearah kebaikan Melalui tuntunan yang dibawa Rasulullah saw. sebagai teladan manusia, memperkokoh kesempurnaan Islam. Syariat Islam sebagai ciri khas peribadatan muslim harus terus dipertahankan dalam konteks teologi dan kelangsungan hidup umat manusia. Sehingga fungsi manusia sebagai khalifah di bumi bisa terus disadarkan.

\section{Pendidikan Islam dalam Pendekatan Interdisipliner}

Fenomena pembelajaran abad 21 terfokus pada penguatan akal. Seperti yang dijelaskan di atas, untuk mengantisipasi meluapnya informasi yang sedang dan akan diterima siswa di masa yang akan datang, kurikulum sebagai satu komponen dalam perencanaan pembelajaran yang berorientasi teknologi digital menjadi penting. Teknologi digital digunakan sebagai alat untuk melatih siswa berfikir kreatif dan inovatif. Penelitian tentang model pembelajaran project base learnig, cooperative learning yang menggunakan teknologi informasi web 20 merupakan model pembelajaran integratif dan sesuai dengan prinsip pembelajaran abad 21 yang berprinsip pada komunikasi, kolaborasi, berfikir kritis, dan berfikir kreatif. ${ }^{16}$ Penelitian tentang penggunaan satu laptop satu anak yang dilakukan di Catalonia menunjukkan terjadi penurunan nilai siswa. Oleh karena itu sebaiknya mepertimbangkan dengan cermat jika ingin menerapkan teknological. ${ }^{17}$ Kemudian temuan penelitian yang berbeda menunjukkan peluang dan tantangan unik yang dihadapi guru dalam mendidik kewarganegaraan global dan menyarankan perlunya mengintegrasikan pendidikan kewarganegaraan global dalam program pendidikan guru melalui pendekatan holistik. ${ }^{18}$

Sisi lain diberlakukannya perdagangan bebas antar negara Asean atau lebih dikenal dengan sebutan Masyarakat Ekonomi Asean (MEA), industrialisasi, dan globalisasi yang berimplikasi pada persaingan lulusan dan pekerjaan semakin berat, dengan berbagai macam persoalan yang sangat kompleks. Salah satu persolan yang paling nampak adalah terjadinya fenomena tenaga 


\section{Fastabiq: Jurnal Studi Islam}

ISSN 2723-0228

Volume 1 Nomor 1 Juni 2020

kerja yang mendapatkan pekerjaan atau posisi tidak sesuai dengan tingkat pendidikan yang ditamatkan. ${ }^{19}$ Dampak globalisasi begitu terasa, kita harus bekerja keras memberikan solusi agar lembaga pendidikan Islam bisa menerima pembelajaran abad 21 dengan baik.

Pendidikan Islam sebagai satu disiplin ilmu yang mempunyai karakter spiritual yang kuat, saatnya menambah keterampilan hidup dengan menyesuaikan pada keterampilan abad 21 yaitu keterampilan berkomunikasi, berkolaborasi, kritis dan berfikir kreatif. Ditinjau dari Sejarah Pendidikan Islam keterampilan abad 21 ini bukan hal baru, 1) Islam sepanjang sejarah pendidikan menekankan konsep Akal, berbagai kemajuan yang ditunjukkan Islam dibidang pemikiran dari mulai zaman Rasulullah, KhulafaurRasyidin, para sahabat sebagai contoh. Suatu saat, Rasulullah saw kepada Khalid bin Walid ketika pertama kali menyatakan keislamannya. "Sungguh, aku memandang bahwa kamu memang memiliki akal, yang kuharap ia tidak menuntunmu kecuali pada kebaikan." Akal menempati potensi tertinggi dalam penciptaan manusia. Secara teologis akal merupakan instrumen untuk mewujudkan tugas kekhalifahan manusia di muka bumi. Kemajuan dalam bidang keilmuwan tidak terbantahkan dalam konsep sejarah Islam. Ini menunjukkan kemajuan berfikir umat Islam sudah mencapai satu puncak kejayaan umat manusia saat itu.

2) Konsep teologi, manusia mempunyai instrumen manifestasi Tuhan berupa akal dan hati nurani. Sebagai wakil Tuhan manusia harus berfungsi melaksanakan fungsi kemanjerialan Tuhan di muka bumi. Akal dan hati diciptakan Tuhan supaya manusia senantiasa berdialog kepadaNya. Tuhan menyukai hambaNya yang berdialog kepadaNya dalam setiap ibadah contohnya kewajiban shalat 5 waktu.

3) Konsep Komunikasi, manusia secara naluriah adalah makhluk komunikasi. Momen kreativitas tidak akan terjadi tanpa berdialog kepadaNya. Dalam surat Al-Baqarah ayat $258 \mathrm{lbrahim}$ berkata, "Tuhanku ialah Yang menghidupkan dan mematikan."la (Namrud) berkata, "Aku dapat menghidupkan dan mematikan." Ibrahim berkata, "Sesungguhnya Allah menerbitkan matahari dari timur, maka terbitkanlah dia dari barat." Lalu terdiamlah orang kafir itu."

4) Kolaborasi atau kerjasama team work. Penjelasan tentang komunikasi berkaitan erat dengan kerjasama. Momen dialog dengan Tuhan akan melahirkan kreativitas baru yang dimuati pesan kebaikan sebagai cahaya Tuhan. Momen dialog manusia ada pada komunikasi manusia dengan manusia, manusia dengan makhluk sekitar, dan manusia dengan alam/lingkungan. Saling tolong menolonglah kamu dalam kebajikan dan ketakwaan dan janganlah kamu saling tolong menolong dalam permusuhan dan dosa."(QS. AI-Maidah:2). Komunikasi antara kelompok manusia yang mempunyai kesamaan disebut komunitas. Dalam satu difinisi komunikasi organisasi sebagai proses menciptakan dan saling menukar pesan dalam satu jaringan hubungan yang saling tergantung satu sama lain untuk mengatasi lingkungan yang tidak pasti atau selalu berubah-ubah. ${ }^{20}$

\section{Lembaga Pendidikan dan Kurikulum Pembelajaran Abad 21 dalam Perspektif Disipliner dan Interdisipliner}

Disipliner dan interdisipliner seperti yang sudah dijelaskan di atas masing-masing mempunyai runutan tersendiri dalam pendidikan Islam. Penulis akan memfokuskan pada dua hal 


\section{Fastabiq: Jurnal Studi Islam}

ISSN 2723-0228

Volume 1 Nomor 1 Juni 2020

besar dalam permasalahan pendidikan Islam saat ini yaitu lembaga pendidikan Islam dan kurikulum pendidikan Islam. Bagaimana pendekatan konsep disipliner dan interdisipliner menyelesaikan permasalahan ini. Kajian literatur ini akan menjelaskan pendekatan disipliner dalam hal ini konsep teologi dalam pendidikan Islam, dan interdisipliner berbagai disiplin ilmu pendidikan islam dalam memberikan solusi pendidikan dalam pembelajaran abad 21 .

\section{a. Permasalahan lembaga pendidikan islam di era globalisasi hari ini}

Lembaga pendidikan Islam di Indonesia mempunyai corak yang beragam pertama ada yang modern dan ada konvensional. Pendidikan Islam menurut Zakiah Darajat aktivitas dan sistem pendidikan yang diselenggarakan atau didirikan untuk mengejawantahkan nilai-nilai pendidikan Islam sehingga terbentuk pribadi muslim yang insan kamil. ${ }^{21}$ Ahmad Tafsir mengelompokkan lembaga pendidikan berdasarkan fakta nya menjadi lima jenis, yaitu: (1) pondok pesantren, (2) madrasah dan pendidikan lanjutannya, seperti UIN, (3) sekolah Islam (4) pelajaran agama Islam di sekolah dan perguruan tinggi, (5) pendidikan Islam dalam keluarga, masyarakat, dan juga melalui jalur nonformal dan informal. ${ }^{22}$ Dari penelitian terdahulu, lembaga pendidikan pesantren dan madrasah menjadi bahan penelitian menarik dalam menghadapi skill pembelajaran abad 21,

a. Muhammad Shofwan dan Ahmad Habibi, Problematika Pendidikan Islam Abad 21 dan Tantangan Pondok Pesantren di Jambi, penelitian yang dilaksanakan di pondok-pondok pesantren Seberang Jambi menyatakan bahwa terdapat beberapa problematika yaitu kurangnya tenaga pengajar yang berkualitas, metode pengajaran yang masih bersifat tradisional, dan belum banyak variasi, kebijakan kurikulum yang berubah-ubah, fasiltas pendidikan yang belum memadai, dan keterbatasan dana. ${ }^{23}$

b. Tatang Hidayat, Ahmad Syamsu Rizal, Fahrudin, Peran Pondok Pesantren Sebagai Lembaga Pendidikan Islam di Indonesia, Pesantren telah mengalami pembaharuan, dengan tetap mempertahan tradisi kepesantrenan yang baik, meskipun Indonesia mengalami modernisme masih ada pesantren yang mempertahankan sistem pendidikan tradisional. ${ }^{24}$

c. Nur Hidayat, Isu-isu kontemporer Pendidikan Islam tentang Madrasah dan Tantangan Global, Kondisi madrasah saat ini sangat memprihatinkan karena minat masyarakat untuk menyekolahkan anaknya ke madrasah masih rendah. ${ }^{25}$

d. Mawardi Pewangi, Tantangan Pendidikan Islam di Era Globalisasi, Ada tiga tantangan utama yang kini dihadapi oleh pendidikan Islam yaitu kemajuan Iptek, demokratisasi, dan dekadensi moral. Penelitian ini menyarankan kurikulum pendidikan Islam bahwa harus direformasi agar dapat menyiapkan sumber daya unggul, dan siap berkompetensi di era globalisasi. ${ }^{26}$

e. Nur Latifah, Pendidikan Islam di Era Globalisasi, penelitian mengemukan ada 9 kelemahan sekaligus tantang lembaga pendidikan Islam, diantaranya, 1) kualitas lembaga pendidikan Islam secara umum masih menyedihkan, meskipun sudah ada beberapa madrasah yang menyamai kualitas sekolah umum, tetapi secara umum kualitas lembaga pendidikan Islam kurang memadai, 2) Kualitas dan kuantitas guru belum memadai, 3) latar belakang siswa berasal dari kelas menengah ke bawah. Penelitian ini pada kesimpulan meningkatnya heterogenitas nilai di masyarakat, derasnya arus informasi, majunya aspek industri yang mendorong manusia bersifat 


\section{Fastabiq: Jurnal Studi Islam}

ISSN 2723-0228

Volume 1 Nomor 1 Juni 2020

materialistik dimana segala bentuk kemajuan kehidupan diukur oleh hal-hal kebendaan, dan ekonomi. Maka kehadiran pendidikan Islam memberikan alternatif kehidupan yang lebih baik, dengan menyiapkan generasi muslim masa depan yang memiliki intelektual tinggi, berakhlak mulia, dan iman yang kuat. ${ }^{27}$

Begitu banyak artikel yang membahas tentang lembaga pendidikan Islam pesantren dan madrasah, keempat artikel di atas mewakili banyak artikel. Artikel a dan b di atas memberikan informasi bahwa, pesantren di Indonesia jika dilihat dari sisi teknis ada 2 jenis yaitu pesantren moderen dan pesantren tradisional.Pesantren modern adalah pesantren yang sudah mengadopsi nilai pendidikan modern seperti saat ini, dan pesantren yang istiqomah yang tidak terpengaruh oleh era modern, istiqomah dalam mempertahankan nilai-nilai pesantren yang sudah ada.

Pesantren dalam pelaksanaan membekali santrinya dengan materi pembelajaran di Madrasah (formal) menghadapi kendala diantaranya kualitas guru yang belum maksimal, peserta didik kebanyakan berasal dari ekonomi bawah, minat masyarakat untuk menyekolahkan anaknya ke madrasah masih kurang. Sehingga berpengaruh pada kualitas lembaga pendidikan.

Banyaknya pesantren yang mempertahankan nilai-nilai tradisional menunjukkan bahwa pendekatan disipliner masih dilihat oleh pemimpin pesantren sebagai nilai murni yang mampu memberikan nilai-nilai kebaikan; akhlak baik, kepemimpinan, kemampuan dalam menghayati dan mengamalkan nilai-nilai keislaman, dan kemandirian merupakan ciri khas alumni. Potret lain, Pesantren modern yang owner atau Kiainya berorientasi pendidikan modern, terlihat berkembang pesat dengan sarana dan prasarana yang bagus dan lengkap, misalnya gedung bagus lingkungan pesantren yang nyaman, mengundang banyak peminat dengan latar belakang santri dari ekonomi menengah atas. Kurikulum pembelajaran, fasilitas belajar, guru yang berkualitas, ekstrakulikuler yang sesuai dengan minat dan bakat santri menjadi daya tarik para orangtua. Bahkan untuk meningkatkan kualitas pembelajaran beberapa pesantren bermitra dengan kampus atau lembaga pendidikan luar negeri. Ini merupakan skill pembelajaran abad 21 yaitu berkolaborasi, dimana dunia saat ini tanpa sekat. Pesantren modern di Indonesia dipelopori oleh pesantren Gontor Jawa Timur, selain itu di Jawa Barat Pesantren Khusnul Khotimah, Nurul Fikri, Milbos (Maghfiroh Islamic Boarding Schoo). Jawa Barat termasuk mempunyai pesantren terbanyak yaitu 9000 pesantren yang tersebar di seluruh pelosok.

Begitu juga madrasah (formal), seperti yang diungkap peneliti di atas bahwa madrasah dihadapi kendala diantaranya yaitu kualitas guru kurang memadai, peserta didik berasal dari menengah ke bawah. Sementara itu berbeda dengan madrasah (formal) ketika menggunakan pendekatan disipliner semata, maka akan berpengaruh pada kualitas peserta didik dan guru. Guru harus memenuhi standar yang sudah ditetapkan pemerintah misalnya guru Madrasah Ibtidaiyah harus S1. Standar atau batas minimum merupakan ketetapan pemerintah yang harus dilaksanakan. Madrasah yang maju adalah madrsah yang melampui batas minimal. Ini yang disebut pendekatan interdisipliner dimana ada beberapa ilmu serumpun yang bisa mengatasi madrasah, sehingga bisa memenuhi standar yang sudah ditetapkan. 
Fastabiq: Jurnal Studi Islam

ISSN 2723-0228

Volume 1 Nomor 1 Juni 2020

\section{b. Permasalahan Kurikulum Pendidikan Islam di Era Globalisasi Hari ini}

Pendidikan Islam telah mengalami kebekuan yang menyebabkan umat islam perlu mempertimbangkan cara baru menyelesaikan kemunduran umatnya melalui pendidikan yang menyegarkan. ${ }^{28}$ Pendidikan Islam saat ini menuai beberapa kritik karena ketidakmampuannya menangani berbagi isu penting dalam masyarakat. ${ }^{29}$ Pernyataan di atas kiranya menjadi satu peringatan bagi kita dalam merencanakan kurikulum.

Kurikulum merupakan rancangan atau rencana secara sistematis dalam proses pendidikan di satu institusi pendidikan. Kurikulum dalam pelaksanaanya sebaiknya bersifat fleksibel dan mudah menyesuaikan dengan perkembangan situasi yang ada. Kurikulum merupakan komponen pendidikan dalam pendidikan sehingga pelaksanaan proses pendidikan di lembaga berhasil.

Kurikulum pendidikan Islam mempunyai ciri-ciri, pertama adalah kurikulum pendidikan Islam mengutamakan tujuan agama dan akhlak, pemberian materi berdasarkan pada nilai-nilai yang terdapat pada Al-Quran dan Hadis. Kedua, materi yang diberikan seimbang pendidikan jasmani, pengetahuan dan keterampilan. Ketiga, keseimbangan antara manfaat untuk individu dan sosial. Keempat, mencerminkan semangat, pemikiran dan ajaran kurikulum yang cukup luas isi dan kandungannya. ${ }^{30}$

Beberapa peneltian mengungkapkan tentang kurikulum diantaranya :

1. Sumantri, B.A, Pengembangan Kurikulum di Indonesia Menghadapi Tuntutan Kompetensi Abad 21, mengemukakan bahwa kurikulum pendidikan abad 21 berorientasi pada 1) kurikulum berbasis kompetensi, 2) Kurikulum berorientasi pada kecakapan hidup, kurikulum 2013 harus berintegrasi itu demi terwujudnya tujuan pengembangan kurikulum pendidikan yang sesuai dan diharapkan dapat membekali peserta didik dengan skill abad 21.

2. Arif Rahman, Negosiasi Pendidikan Islam, dan Teknologi terhadap Perubahan Global, Kaum Muda, Globalisasi, dan relasinya dengan pendidikan Islam, telah terjadi seiring dengan perjalanan waktu, diawali dari keterlambatan merespon perubahan dan dinamika, pendidikan Islam menyadari bahwa reformasi pendidikan tidak boleh berhenti.

3. Nur Latifah, Pendidikan Islam di Era Globalisasi, hal yang harus menjadi perhatian dalam pendidikan Islam diantaranya adalah kurikulum yang handal dan berwawasan masa kini dan masa depan. Kurikulum ini diharapkan dapat menghasilkan manusia yang memiliki kemampuan berkualitas, dan mempunyai keterampilan dan kecakapan dalam hidup. ${ }^{31}$

4. Zaenudin, Reformulasi Pendidikan Agama Islam, bahwa sistem pendidikan Islam belum mampu menghadapi perubahan dan menjadi counter ideas terhadap globalisasi kebudayaan. Oleh sebab itu pola pengajaran maintenance learning yang selama ini dipandang terlalu bersifat adaptif dan pasif harus segera ditinggalkan. Dengan begitu, maka lembaga pendidikan Islam setiap saat dituntut untuk selalu melakukan rekonstruksi pemikiran kependidikan dalam rangka mengantisipasi setiap perubahan yang terjadi. Kegagalan pendidikan Islam kontemporer secara umum juga disebabkan oleh faktor perumusan visi dan misi yang tidak kompatibel dengan konsep ideal dan kondisi empiriknya. Setidaknya hal ini disebabkan oleh lima alasan 


\section{Fastabiq: Jurnal Studi Islam}

ISSN 2723-0228

Volume 1 Nomor 1 Juni 2020

berikut: Pertama, secara fundamental pengajaran kita tidak fokus pada pengembangan karakter dan kepribadian, tidak sejalan dengan apa yang menjadi perhatian Nabi Muhammad saw. Kedua, kebanyakan yang diajarkan adalah sesuatu yang yang tidak relevan dengan kehidupan riil siswa seperti kebutuhan dan tantangan yang akan mereka hadapi. Ketiga, metode pengajarannya lebih cenderung terpusat pada pengajaran (teaching) bukan pada belajar (learning). ${ }^{32}$

5. Syamsul, Tantangan Abad 21 Reformasi kurikulum sesuai dengan abad 21.Kurikulum harus Update sesuai dengan perkembangan zaman (up date) oleh karena itu reformasi kurikulum biasa dilakukan karena ada tuntutan zaman. ${ }^{33}$

6. Mawardi Pewangi, Tantangan Pendidikan Islam di Era Globalisasi, Ada tiga tantangan utama yang kini dihadapi oleh pendidikan Islam yaitu kemajuan Iptek, demokratisasi, dan dekadensi moral. Penelitian ini menyarankan kurikulum pendidikan Islam bahwa harus direformasi agar dapat menyiapkan sumber daya unggul, dan siap berkompetensi di era globalisasi. ${ }^{34}$

Integrasi kurikulum pendidikan Islam masih meninggalkan pekerjaan rumah terutama pengintegrasian pendidikan Islam ke dalam konsep pembelajaran abad 21. Para peneliti mengungkapkan kesimpulan bahwa kurikulum perlu terus menerus disesuaikan dengan perkembangan zaman. Zaenudin mengungkapkan bahwa tentang kegagalan pendidikan Islam kontemporer yang disebabkan oleh kurang tepatnya dalam merumuskan visi dan misi. Ketidaktepatan merumuskan visi dan misi akan berdampak pada kurang tepatnya dalam merencanakan dan melaksanakan kurikulum.

Penelitian di atas menegaskan bahwa kurikulum merupakann komponen penting dalam dunia pendidikan. Kurikulum yang berada dalam kondisi perubahan yang sangat cepat dan masif ini, menjadi satu keharusan untuk berubah, bernostalgia dengan kejayaan atau keberhasilan sebelumnya bukan hal yang baik. karena hari ini kita hidup dalam dunia yang tidak pasti. Digitalisasi seolah-olah mendrive masyarakat untuk mengikuti cara hidup yang diciptakan dunia maya itu (seperti yang dijelaskan di awal tulisan ini). Solusinya menciptakan kurikulum yang fleksibel, dengan berpegang teguh pada konsep teologi pendidikan Islam. Sehingga outcome yang dihasilkan adalah peserta didik yang siap pada masanya. Oleh karena itu kurikulum harus bisa menyesuaikan diri dengan peradabaan yang serba cepat.

\section{c. Pembahasan Disipliner dan Interdisipliner sebagai Solusi}

Pembelajaran abad 21 yang mengedepankan akal semata, dari perspektif disipliner akan mengakibatkan ketimpangan dalam jiwa seseorang, yang sudah dibahas di atas. Oleh karena itu Pesantren yang eksis melalui pendekatan disipliner ini masih banyak dipercaya masyarakat sebagai lembaga pendidikan agama Islam yang mumpuni yang mampu menjawab segala kekhawatiran masyarakat sebagai dampak dari kemajuan digital tanpa batas. Materi yang diajarkan di pesantren diantaranya mempelajari kitab-kitab berbahasa Arab yang akan menjadi pedoman hidup santri, disiplin, kepatuhan kepada Kiai atau Ajengan, skill sosial misalnya dengan melakukan gotongroyong 


\section{Fastabiq: Jurnal Studi Islam \\ ISSN 2723-0228}

Volume 1 Nomor 1 Juni 2020

bekerja sama, dan mengorganisir satu acara, skill kepemimpinan juga dilatihkan kepada santri, skil seorang dai dan masih banyak lagi.

Lembaga pendidikan Madrasah masih banyak yang di bawah garis standar pendidikan madrasah, contoh di Kota Bandung ada 26 madrasah Aliyah swasta, 2\% mempunyai sarana yang bagus, 30\% madrasah mempunyai gedung yang memadai. Selebihnya sedang berjuang memenuhi standar. Madrasah swasta harus bersaing dengan sekolah umum yang mempunyai fasilitas yang memadai terlebih bersaing dengan SMK yang banyak digandrungi oleh masyarakat. Lembaga pendidikan yang berada di bawah standar masih meninggalkan pekerjaan serius bagi lembaga itu sendiri. Karena tidak ada pihak yang bisa menjamin dan menaggung, meskipun lembaga tersebut diberi izin operasional oleh pihak yang berwenang, namun kausul untuk mencabut kembali izin sepertinya sulit di lakukan. Maka ini akan menjadi pembiaran yang berlangsung terus menerus, secara umum diserahkan kepada mekanisme masyarakat dan mekanisme digitalisasi adminstrasi sekolah atau madrasah.

Kemajuan dunia digital memperlihatkan sisi positif dan sisi negatif, Mawardi Pewangi mengungkapkan ada tiga tantangan utama yang kini dihadapi oleh pendidikan Islam yaitu kemajuan Iptek, demokratisasi, dan dekadensi moral. Dekadensi moral ini serius terjadi di sekolah, madrasah, dan ada juga terjadi di pesantren. Misalnya kasus pelajar di Bandung, berawal dari saling sindir dan hina di medsos, yang berakhir pada pengrusakan 2 Sekolah Menengah Atas di Kota Bandung. ${ }^{35}$ murid memukul dan bahkan membunuh guru, demo siswa SMA pertengahan dan diakhir tahun 2019 merupakan fenomena. Ini potret pendidikan yang harus kita hadapi dan dicarikan akar permasalahan dan solusi.

Hasil penelitian dan kenyataan di lapangan menunjukkan bahwa jumlah lembaga pendidikan pendidikan Islam lebih banyak yang masih berjuang mencapai standar, dibanding yang lembaga pendidikan Islam yang sudah memadai dan bagus, masyarakat yang kurang percaya untuk menyekolahkan putra putrinya ke Madrasah, menunjukkan bahwa kinerja lembaga pendidikan tersebut masih di bawah standar. Sementara kurikulum menuntut kepada guru terutama untuk memprioritas proses belajar mengajar yang memenuhi standar yang sudah berlaku umum. Analisa konsep disipliner dan interdisipliner menjadi solusi dari permaslahan diatas. Pendekatan disipliner meski sudah lama dianut dalam pendidikan Islam dalam merancang kurikulum atau menyelesaikan problem pendidikan, masih cukup kuat. Banyak lembaga pendidikan yang masih bertahan misalnya lembaga pendidikan formal yang dimiliki individu atau yayasan keluarga. Terutama pesantren yang masih mempertahankan nilai tradisional dan mengandalkan ketokohan seorang Kiai. Lembaga ini dipandang berhasil di zamannya, dan sekarangpun masih eksis. Bukti eksistensi pesantren tradisional masih eksis misalnya pengerahan ribuan santri pada gerakan 212, dan kejadian Mei 2019 yang melibatkan santri turun ke jalan. Konsep disipliner teologis dan ketokohan seorang Kiai membuktikan bahwa pesantren masih diminati banyak orang tua santri.

Konsep teologi pendidikan Islam bisa kita runut dari konsep fitrah dan khilafah. Fitrah atau kesucian, setiap manusia lahir ke dunia suci batin dan suci jasmani. Fitrah diarahkan pada pemahaman bahwa manusia lahir membawa potensi diri. Potensi yang sudah disediakan Allah untuk 


\section{Fastabiq: Jurnal Studi Islam \\ ISSN 2723-0228}

Volume 1 Nomor 1 Juni 2020

setiap manusia yang diciptakanNya. Potensi ini akan menjadi cikal bakal perkembangan manusia, yang berkembang dan bertumbuh sesuai dengan kondrat manusia. Berdasarkan konsep ini, maka tempat manusia kembali baik secara lahir maupun batin hanya kepada Allah.

Fitrah dan khalifah merupakan konsep jati diri manusia yang merdeka. Dengan potensi akalnya manusia mampu berkomunikasi, menciptakan sesuatu hal yang baru, dengan potensi khalifahnya manusia memelihara alam sesuai dengan kaidah-kaidah kebenaran Tuhan. Ini disebut kemerdekaan diri. Menurut Paulo Friere, fitrah manusia sejati sebagai subjek atau pelaku yang sadar bertindak mengatasi kehidupan dunia yang menghimpit, Manusia harus menghadapi segala persoalan kehidupan secara kritis. ${ }^{36} \mathrm{Di}$ sini letak abdullah, penghambaan manusia terhadap Allah. Konsep ini menjadi satu kesadaran batin bahwa fungsi manusia adalah sebagai abid dan khalifah Allah. Maka kesadaran akan peran abid dan peran khalifah menjadi hal penting dalam perjalanan seorang anak manusia. Seorang owner madrasah merasakan peran abid, makanya akan berusaha sebaik mungkin menjalankan amanah Allah untuk mendidik siswa. Begitupun sebaliknya seorang guru yang mempunyai kesadaran teologis; kesadaran akan peran kita dimasyarakat akan menggiring untuk melakukan pekerjaan yang terbaik, mengingat siswa adalah amanah Allah yang harus dikembangkan potensi dalam diri.

Pendekatan interdisipliner merupakan pemecahan permasalahan melalui pendekatan ilmu serumpun. IImu pendidikan Islam melahirkan banyak ilmu, diantaranya: filsafat pendidikan Islam, ilmu pendidikan Islam, psikologi pendidikan Islam. Implementasi interdisipliner dalam pendidikan Islam ada di pesantren modern dan madrasah formal. Dalam dekade 15 tahun terakhir bermunculan lembaga pendidikan yang menamakan boarding school yang memadukan ilmu sains dan ilmu agama. Seperti lembaga pendidikan yang dirancang oleh Departemen Agama satu diantaranya adalah Madrasah Aliyah Cendekia Serpong yang berawal dari ide cemerlang ICMI saat itu. Terbukti menghasilkan lulusan yang berkualitas dan mendapatkan beasiswa ke Nanyang University Singapore (pada saat itu bea siswa langka). MAN Cendekia Serpong ini menjadi pilot project yang selanjutnya MAN didirikan di beberapa propinsi. Masih banyak lembaga pendidikan yang memadukan pembelajaran sains dan ilmu agama secara bersamaan yang dikelola yayasan atau lembaga pendidikan swasta.

Pendidikan Islam mampu berinovasi dalam kurikulum sesuai dengan tuntutan keterampilan pembelajaran abad 21 yang terdiri dari 4 hal yaitu komunikasi, kreativitas, kolaborasi dan kreativitas dalam berfikir. Terbukti banyak lembaga pendidikan Islam sudah mengembangkan skill pembelajaran abad 21. Lembaga pendidikan Islam modern seperti Pesantren Gontor, Pesantren Husnul Khotimah, pesantren Milbos dan banyak lagi adalah pesantren yang secara tidak langsung telah menerapkan keterampilan abad 21. Kesadaran insan pendidikan akan pentingnya kurikulum merupakan kesadaran diri sebagai abid dan khalifah Allah. Kurikulum berlandaskan konsep teologi dan rumpun ilmu pendidikan Islam ditambah multidisipliner menjadi satu kesatuan yang utuh tiga konsep yatu konsep teologis, konsep ilmu keislaman, konsep kebudayaan/kenegaraan.

Nilai yang terkandung dari disipliner dan interdisipliner dalam konteks nilai-nilai Islam mampu menyesuaikan dengan perkembangan dan mampu menyiapkan peserta didik dengan keterampilan 


\section{Fastabiq: Jurnal Studi Islam}

ISSN 2723-0228

Volume 1 Nomor 1 Juni 2020

abad 21. Dari perspektif disipliner dan interdisipliner permasalahan di dunia pendidikan bisa teratasi dengan cara mengembalikan semua komponen pendidikan pada konsep teologis dan konsep interdisipliner. Bagi Pendidikan Islam permasalahan yang esensi mungkin bukan pada konsep tetapi permasalahan yang bermunculan sekarang adalah pada sumber daya manusia, akhlak dalam berkomunitas, dan kesepakatan membangun bersama peradaban Islam.

\section{SIMPULAN}

Pembelajaran abad 21 bukan hal baru sebenarnya. Mengingat era digital ini menawarkan kemudahan dan juga menawarkan pembiayaan tinggi, yang sebagian lembaga pendidikan belum memprioritaskan, sehingga penggunaan digital belum sepenuhnya terlaksana. Pentingnya mengimplementasikan pendekatan teologis dan interdisipliner dalam pendidikan Islam pada tatanan praktis saling terkait. Beberapa contoh di atas membuktikan bahwa dua pendekatan konsep dapat menyesuaikan pendidikan islam dan pembelajaran abad 21 dalam menyelesaikan masalah pendidikan lembaga dan kurikulum pendidikan. Riset disipliner dan interdisipliner bisa mengintegrasi digitalisasi era dalam satu konsep Pendidikan Islam. Integrasi ini secara teologis saling mendukung untuk membentuk satu tujuan yaitu manusia yang insan kamil. 


\section{ENDNOTES}

${ }^{1}$ Piliang, Yasraf Amir, 2000. Sebuah Dunia yang dilipat. Bandung: Mizan.

${ }^{2}$ Meyrowitz, Joshua. 1999. "Understanding' of Media." ETC.:A Review of General Semantics (Vol. 56, Issue 1)

${ }^{3}$ Arif Hidayatullah, Wahidul Anam, Moh. Zaenal Fanani, Problematika K13 dalam Pembelajaran PAI, Jurnal Edudeena Vol 1, No. 2, 2017, h. 63.

${ }^{4}$ Musrifah," Analisis Kritis Permasalahan Pendidikan Islam Indonesia Di Era Globalisasi," dalam Jurnal Islamic Studies and Humanities, Vol 3, No. 1, 2018, h. 67.

${ }^{5}$ Saripudin, Pengembangan Model Pembelajaran Abad 21, Jurnal Teknodik, Vol 19, No. 1, 2015 h.2.

${ }^{6}$ M.Quraish Shihab, Tafsir Al-Misbah, Lentera Hati, Jakarta, 2002, h.678.

${ }^{7}$ Patricia C. Seifert,

${ }^{8}$ Darajat, Zakiah. 1994. IImu Pendidikan Islam. Jakarta: Bumi Aksara

${ }^{9}$ Al Ghazali, Muhammad Abu Hamid bin Muhammad. 2020. Ihya Ulumuddin. Bandung: Marja.

${ }^{10}$ John Creswell, Riset Pendidikan, Jakarta, Pustaka Pelajar, 2015, h.140.

${ }^{11}$ Ayat Dimyati, Tauhid IImu, Bandung, BTM, 2016, hal. 23.

${ }^{12}$ Darajat, Zakiah. 1994. IImu Pendidikan Islam. Jakarta: Bumi Aksara

${ }_{14}^{13}$ Haidar Bagir, Akhlak Tasawuf, Bandung, Mizan, 2015, hal.19.

${ }^{14}$ Abdul Khakim," Hak Asasi Manusia Dalam Perspektif Pendidikan Islam," dalam Jurnal Evaluasi Vol. 2 No.1 Maret 2018 h.377.

${ }^{15}$ Sudirman Sommeng, "Model Pendidikan Islam Yang Berwawasan Hak Azasi Manusia (HAM)," dalam Al-Irsyad Jurnal Al-Nafs, 2014 h.78.

${ }^{16}$ Saripudin,"Pengembangan Model Pembelajaran Abad 21," Jurnal Teknodik, Vol.19, No. 1, 2015, h.2.

17 Toni Mora ${ }^{\mathrm{a}}$, Josep-Oriol Escardíbul ${ }^{\mathrm{b}}$, Giorgio Di Pietro,"Computers and students' achievement: An analysis of the One Laptop per Child program in Catalonia," Elsiever International Journal Research 92, 2018, h.145-157.

${ }^{18}$ Linyuan Guo," Preparing Teacher to Educated 21th Century Global Citizenchip: Envisioning, and Encating," dalam Journal of Global Citizenship \& Equity Education Volume 4 Number 1 - 2014 h.3.

19 Chanifudin,"Pendekatan Interdisipliner:Tata Kelola Pendidikan Islam Di Tengah Kompleksitas," dalam Edukasi Islami Jurnal Pendidikan Islam,Vol. 5 Januari 2016 h.1277.

${ }^{20}$ Arni Muhammad, Komunikasi Organisasi, Jakarta, PT Bumi Aksara, 2014, h.67.

${ }^{21}$ Zakiah Darajat, IImu Pendidikan Islam, Jakarta, Bumi Aksara, 1994, h. 28.

22 Ahmad Tafsir, IImu Pendidikan Islam dalam Perspektif Islam, Bandung, PT. Remaja Rosdakarya, 2005 (cet.6), h.

${ }^{23}$ Muhammad Shofwan dan Ahmad Habibi," Problematika Pendidikan Islam Abad 21 dan Tantangan Pondok Pesantren di Jambi," dalam Jurnal Kependidikan Volume 46, No. November 2016, h. 271.

24 Tatang Hidayat, Ahmad Syamsu Rizal, Fahrudin," Peran Pondok Pesantren Sebagai Lembaga Pendidikan Islam di Indonesia," dalam Jurnal Ta'dib, Vol. 7, No. 2, 2018, h.461.

${ }^{25}$ Nur Hidayat, "Isu-isu kontemporer Pendidikan Islam tentang Madrasah dan Tantangan Global," Jurnal ......Vol 2, No. 1, 2010, h. 4

${ }^{26}$ Mawardi Pewangi," Tantangan Pendidikan Islam di Era Globalisasi," Jurnal Tarbawi Vol.1, No.1 h.1

${ }^{27}$ Nur Latifah," Pendidikan Islam di Era Globalisasi, Palapa, Jurnal Studi Keislaman dan Pendidikan," Vol 5, No.1, Mei 2017, h. 196.

${ }^{28}$ Fazlurrahman, Islam, The University of Chicago Press, t.t., h.330

${ }^{29}$ Sutrisno, Revolusi Pendidikan: Membedah Metode dan Teknik Pendidikan Berbasis Kompetensi, Yogyakarta, Arruz, 2006, h.5.

30 Omar Mohammad Al-Toumy Al-Syaibany, Falsafah Pendidikan Islam, Jakarta, Bulan Bintang, 1979. h.512.

${ }^{31}$ Nur Latifah," Pendidikan Islam di Era Globalisasi," dalam Palapa Jurnal, Vol. 5 No 1, 2019.

${ }^{32}$ Zaenudin, Reformulasi Pendidikan Agama Islam, Gema, Nov 2013.

${ }^{33}$ Syamsul Kurniawan, "Tantangan Abad 21 Bagi Madrasah di Indonesia," dalam Jurnal Intizhar, Vol.25 No 1 Juni 2019, h.55.

${ }^{34}$ Mawardi Pewangi," Tantangan Pendidikan Islam di Era Globalisasi," dalam Jurnal Tarbawi Vol. 1, No. 1 h.1. 
Fastabiq: Jurnal Studi Islam

ISSN 2723-0228

Volume 1 Nomor 1 Juni 2020

${ }^{35}$ https://bandung.kompas.com/read/2019/10/29/11364741/polisi-sebut-perusakan-sekolah-dibandung-murni-kriminal

${ }^{36}$ Paulo Freire, Politik Pendidikan: Kebudayaan, Kekuasaan, dan Pembebasan, hlm.vii-ix. Lihat juga Ibniyanto, " Humanisme Teosentris Sebagai Paradigma Ideologi Pendidikan Islam: Studi Buku Ideologi Pendidikan Islam: Paradigma Humanisme Teosentris, Karya Achmad", (Skripsi Sarjana Universitas Islam Negeri Sunan Kalijaga, Yogyakarta, 2010), hlm.56. 


\section{REFERENSI}

Abdul Khakim, Abdul. 2018," Hak Asasi Manusia Dalam Perspektif Pendidikan Islam," Jurnal Evaluasi Vol. 2 No.1.

Achmad, Karya,"Humanisme Teosentris Sebagai Paradigma Ideologi Pendidikan Islam: Studi Buku Ideologi Pendidikan Islam: Paradigma Humanisme Teosentris," (Skripsi Sarjana Universitas Islam Negeri Sunan Kalijaga, Yogyakarta, 2010).

Al Ghazali, Muhammad Abu Hamid bin Muhammad. 2020. Ihya Ulumuddin. Bandung: Marja

Bagir, Haidar. 2015. Akhlak Tasawuf. Bandung: Mizan.

Chanifudin ,"Pendekatan Interdisipliner: Tata Kelola Pendidikan Islam Di Tengah Kompleksitas," Edukasi Islami Jurnal Pendidikan Islam ,Vol. 5 Januari 2016.

Darajat, Zakiah. 1994. IImu Pendidikan Islam. Jakarta: Bumi Aksara.

Dimyati, Ayat. 2016. Tauhid IImu. Bandung:BTM.

Fazlurrahman. tt. Islam, The University of Chicago Press.

Hidayat, Tatang; Ahmad Syamsu Rizal, Fahrudin," Peran Pondok Pesantren Sebagai Lembaga Pendidikan Islam di Indonesia," Jurnal Ta'dib, Vol 7, No. 2, 2018.

Hidayatullah, Arif; Wahidul Anam, Moh. Zaenal Fanani. 2017," Problematika K13 dalam Pembelajaran PAI," dalam Jurnal Edudeena Vol 1, No. 2.

https://bandung.kompas.com/read/2019/10/29/11364741/polisi-sebut-perusakan-sekolah-di-bandungmurni-kriminal

John Creswell. 2015. Riset Pendidikan. Jakarta: Pustaka Pelajar.

Linyuan Guo, Preparing Teacher to Educated 21th Century Global Citizenchip: Envisioning, and Encating, Journal of Global Citizenship \& Equity Education Volume 4 Number 1 - 2014 hal 3

Mawardi Pewangi, Tantangan Pendidikan Islam di Era Globalisasi, Jurnal tarbawi Vol 1, No. 1 h.1

Meyrowitz, Joshua. 1999. "Understanding of Media." ETC.:A Review of General Semantics (Vol. 56, Issue 1)

Mohammad, Omar Al-Toumy Al-Syaibany. 1979. Falsafah Pendidikan Islam.Jakarta: Bulan Bintang.

Muhammad, Arni. 2014. Komunikasi Organisasi. Jakarta: PT Bumi Aksara.

Musrifah. 2018," Analisis Kritis Permasalahan Pendidikan Islam Indonesia Di Era Globalisasi," dalam Jurnal Islamic Studies and Humanities, Vol 3, No. 1.

Nur Latifah, "Pendidikan Islam di Era Globalisasi," Palapa, Jurnal Studi Keislaman dan Pendidikan, Vol 5, No.1, Mei 2017.

Nur Hidayat, Isu-isu Kontemporer Pendidikan Islam tentang Madrasah dan Tantangan Global, Vol 2, No. 1, 2010.

Piliang, Yasraf Amir, 2000. Sebuah Dunia yang dilipat. Bandung: Mizan

Quraish, M. Shihab. 2002. Tafsir Al-Misbah. Jakarta: Lentera Hati.

Saripudin. 2015," Pengembangan Model Pembelajaran Abad 21," Jurnal Teknodik, Vol 19, No. 1.

Sutrisno. 2006. Revolusi Pendidikan: Membedah Metode dan Teknik Pendidikan Berbasis Kompetensi. Yogyakarta: Arruz.

Shofwan, Muhammad dan Ahmad Habibi, "Problematika Pendidikan Islam Abad 21 dan Tantangan Pondok Pesantren di Jambi," dalam Jurnal Kependidikan Volume 46, No. . November 2016.

Syamsul Kurniawan, "Tantangan Abad 21 Bagi Madrasah di Indonesia," Jurnal Intizhar, Vol.25 No 1 Juni 2019. 
Fastabiq: Jurnal Studi Islam

ISSN 2723-0228

Volume 1 Nomor 1 Juni 2020

Sudirman Sommeng, Sudirman. 2014," Model Pendidikan Islam Yang Berwawasan Hak Azasi Manusia (HAM)," Al-Irsyad Jurnal Al-Nafs.

Toni Mora', Josep-Oriol Escardíbul, Giorgio Di Pietro. 2018," Computers and students' achievement: An analysis of the One Laptop per Child program in Catalonia," Elsiever International Journal Research 92, h.145-157.

Tafsir, Ahmad. 2005. Ilmu Pendidikan Islam dalam Perspektif Islam. Bandung: PT. Remaja Rosdakarya (Cet.6).

Zaenudin. 2013. Reformulasi Pendidikan Agama Islam. Bandung: Gema Insani Press. 